\title{
Moving occupation into treatment: clinical interpretation of "legitimizing occupational therapy's knowledge".
}

Janice P. Burke

Thomas Jefferson University

Follow this and additional works at: https://jdc.jefferson.edu/otfp

Part of the Occupational Therapy Commons

Let us know how access to this document benefits you

\section{Recommended Citation}

Burke, Janice P., "Moving occupation into treatment: clinical interpretation of "legitimizing occupational therapy's knowledge"." (1996). Department of Occupational Therapy Faculty Papers. Paper 42.

https://jdc.jefferson.edu/otfp/42

This Article is brought to you for free and open access by the Jefferson Digital Commons. The Jefferson Digital Commons is a service of Thomas Jefferson University's Center for Teaching and Learning (CTL). The Commons is a showcase for Jefferson books and journals, peer-reviewed scholarly publications, unique historical collections from the University archives, and teaching tools. The Jefferson Digital Commons allows researchers and interested readers anywhere in the world to learn about and keep up to date with Jefferson scholarship. This article has been accepted for inclusion in Department of Occupational Therapy Faculty Papers by an authorized administrator of the Jefferson Digital Commons. For more information, please contact: JeffersonDigitalCommons@jefferson.edu. 


\section{Moving Occupation Into Treatment: \\ I}

Clinical Interpretation of "Legitimizing Occupational Therapy's Knowledge"

Janice Posatery Burke

Key Words: health • history of occupational therapy $\bullet$ human activities and occupations $\bullet$ purposeful activity
Janice Posatery Burke, MA, OTR/L, FAOTA, is Assistant Professor, Department of Occupational Therapy, College of Allied Health Sciences, Thomas Jefferson University, Edison 820, 130 South 9th Street, Philadelphia, Pennsylvania 19107.

This article was accepted for publication June 14, 1996. $f$, as Wood (1996) encourages, occupational therapists seize the opportunity to further develop their knowledge and communicate the societal values that are inextricably bound to their practice, they will undoubtedly march into the 21 st century with an excitement and enthusiasm that will revolutionize the scope and depth of occupational therapy. Therapists will be able to work in a grearly expanded range of settings, delivering a wide band of service. In addition to continuing our efforts with persons who are chronically ill, we will intervene with persons who suffer from the chronic problems that resulc from poverty and being disadvantaged, who confront new kinds of disruptions and displacement due to newly emerging corporate practices (e.g., downsizing and rightsizing, which are quickly making the idea of full-time, long-term work obsolere), and who wish to engage in preventive and wellness activity. In these extended roles, we would be focusing our atrention on how occupation can be addressed in evaluation, treatment, and measurable outcomes.

The recognition that occupational therapists are the keepers of knowledge pertaining to "adaptation through occupation... [that] has historically constituted occupational therapy's unique domain of concern" (Wood, 1996, p. 626) is both exciting and empowering but also somewhat threatening. As a clinician, I ask myself, "Why have occupational therapists been so unwilling to articulate their core concepts?" The reasons seem to be many.

Without question, external factors have impinged on our development of a knowledge base. Certainly, our unlikely partnership within medicine and the hard sciences has stifled our perspective and diverted our attention. Placed in a world where the primary orientation is directed toward solving problems of acute pathology and the reduction of disease through drugs and surgery, our commitment to persons with severe and chronic disabilities has been compromised. Our discomfort with repeatedly addressing issues of function within an environment that has, until recently, shown only nominal interest in the concept has resulted in our taking a backseat to our own knowledge development.

Compounding our limited attention to developing an increased understanding of how we promore occupation through adaptation has been a lack of interest in treatment protocols, program development, and research projects from outside interest groups (e.g., administrators, managers, grant and special project officers) that would facilitate the kind of work that would contribure to the fundamental core of our field. We have been out- 
siders in the world of external funding for research and development, and as such, we have been unable to find the resources and support to engage in the kind of thinking that promises to expand our understanding of occupation; as citizens in a reductionist world, we have been unable to recognize and make use of evaluation, documentation, and research methods that fall outside of the dominant medical-scientific model. For example, our failure to consider the use of the phenomenological perspective has limited the type and scope of inquiry we can make into occupation. It is difficult to sit among a group of professionals who value cause-effect understanding of illness and disease and initiate or pose questions regarding environmental press, just-right challenge, and selfinitiated activity.

Turning inward, I can name a host of internally based reasons for occupational therapists' failure to understand and embrace "the very heart of clinical practice" (Wood, 1996, p. 628). As Wood (1996) outlined, the elements of adaptation through occupation are exceedingly complex and densely woven into the tapestry of our work. The adaptive responses that are elicited through occupational therapy are multidimensional, far reaching in their effects, difficult to organize, and difficult to explain. Indeed, in response to reading about them, I wonder: "Do we avoid bringing our work into sharp focus because we fear that we will not be able to explain, and thus prove, that what we do makes a difference? Are we put off by the recognition that occupation has a profound effect on behaviors that go beyond the activity selected in any given session?" We are faced with the daunting task of understanding and explaining what it means to work in a meaningful way with a patient. The effect of that work plays out in a wide range of occupationally related behaviors that go beyond the boundaries of our clinic walls and the limits of our timed sessions, which can seem overwhelming to any therapist who is faced with an increasing caseload and dwindling time.

Does our uneasiness about how to explain and claim credit for the success cause us to ler successes go undocumented and responsibility go unstated? In my own practice, I am constantly confronted by the need to find ways to say what I intuitively believe-the knowing how part of myself. For example, when a father brings his son to therapy and proudly reports that his son's teacher is noticing an improvement in the boy's handwriting, I am confronted by the absence of cut-and-dry definitive proof that I have contributed to these changes. I must make the connection (for the father and myself) that the activities I provided (e.g., purting small objects into the boy's hands; providing him with opportunities to play with toys that would help develop the intrinsic muscles and arches of his hand; coaxing eye-hand coordination; increasing strength, mobility, and interest in manipulation of small objects) directly facilitated the boy's process of adaptation through occupation. Similarly, when I work on a project, such as making a pot holder with a 9year-old girl who has a poor fine motor skill, poor selfconcept, and low self-esteem, I cannot assume that the mother or teacher will definitively associate what goes on in occupational therapy with positive changes at home and school. We expect the changes that are reported to be widespread and system oriented because of the multidimensional nature of occupation and the integrative effect of activity on the person, yet they are very hard to point to specifically.

The power of occupation has been easier to explain when my ideas about occupation were applied to the organization and transformation of an occupational therapy department. Several years ago, I agreed to participate in redesigning an occupational therapy department in a moderate-sized rehabilitation hospital. In an effort to provide a consistent philosophy and approach to care (evaluation and treatment), the director of the department asked me to initiate a series of in-services, workshops, and related projects that would transform the staff members and treatment setring into an occupation-oriented environment. Beginning with the introduction and adoption of a common language to talk about patient problems and solutions, we adopted the Model of Human Occupation as an organizing framework for thinking and doing; this served as a unifying perspective to guide practice. The project, which was implemented over a period of months, resulted in the physical reorganization and redevelopment of the department (changing not only the organization and location of supplies and treatment materials, but also the actual objects that would be used to provide occupational therapy) as well as a redistribution of staff member efforts.

The power of a unifying framework as a basis for organizing ideas and actions cannot be overstated. After the participating therapists embraced the language and focused on human occupation as the hinge for their practice, there was no stopping them. They organized into work groups on the basis of their own interests as well as their day-to-day needs. We had countless spin-offs from our main project, including the development and implementation of a mentoring system for new therapists joining the department (which first resulted in a manual for the department and later as a published book). Ano- 
ther spin-off was an environment team that first brainstormed ideas and later created and built treatment stations (e.g., a home repairs station, a home maintenance station) based on the patient groups that were most commonly treated in the setting and patient requests concerning their occupational needs. Treatment changed. Therapists are now able to interview a patient then go to the cabinet and find what they need. For example, a woman spoke of her occupation as homemaker and the confusion she experienced subsequent to her stroke. The therapist was able to reach for a kit filled with a set of dishes, napkins, and silverware to practice with the woman the organizational and problem-solving skills needed for table setting. Similar kits for check writing or list writing are also available to the therapist in this department.

\section{Making Professional Changes: A Shift in Direction}

As we publicly clarify the relationship berween occupation and function, we will need to develop a host of new skills, especially those grounded in the art of confrontation and negotiation. We will need to recognize that we are not a technical or adjunctive therapy that can quietly contribute to patient improvement in an additive way. Rather, we are central to the therapeutic process, designing and directing a much larger and more definitive change in the persons receiving our service. Consequently, more attention will be on us, more questions will be asked, and more answers will be needed. We will transform ourselves into key players in the restoration of health and function through occupation rather than stand by as supportive, silent partners.

That everything around us is changing provides a tremendous imperus for practicing therapists to take some new and innovarive steps to understanding the practice of occuparional therapy. As I think about moving toward an expanded understanding of occupation, I have the need to create some basic rules about what must be in place, in the treatment environment as well as in myself, if I am to make the best use of the time and ideas that will be generated around occupation in any given treatment session.

Along with Wood's (1996) explication of four key elements of organizing knowledge concerning the adaptive process of occupational therapy, I am adding a few specifications of my own for the treatment environments in which I interact:

1. The environment I create in my clinic, a home, a school, or a community must hold a sense of excitement, novelty, and intrigue for the parient as well as myself. I can do this by creating situations where the patient can explore a field of choices during each therapy session. I must find a way to provide the parient with the opportunity to experience a feeling of possibilities to be explored.

2. The environment must be equipped with what I really need. Just as therapists in the rehabilitation setting who work with patients who occupy their time doing simple home repairs need access to simple electrical wiring and plumbing setups, I need access to the occupations my patients engage in.

3. I need to advocate for access to environments, such as the middle school science classroom where a student needs assistance with organizing materials while the science experiment is going on. I can no longer allow myself to be segregated in a one-toone treatment interacrion that removes the person and the therapist from the actual situation that is problematic.

When I reflect on myself as a therapist, I must recognize that I will need:

1. To know what questions to ask: Who is this person? What does he or she care about? How can I shape this session to be a turning point for him or her?

2. To think about this patient as an occupational creature. I need to look at each person as functioning within an occupational world that is defined by special cultural preferences, interests, and values.

3. To develop systems that help me organize and share my thinking. I need to find a way to document my reflections and ideas from one treatment session to another by keeping a journal, maintaining some kind of coding system based on ideas that I generate during treatment about occuparion, taking and watching videotapes of sessions, and finding another therapist to be my partner in this kind of thinking.

4. To develop and try out new ideas all the time.

5. To spend more time watching myself and others engage in occupation. These observations will give me ideas about how a person's occupational nature drives the choices that are made during leisure, work, and rest time.

6. To promote what I do by providing clear and understandable explanations to my referral sources (e.g., physicians, case managers, health 
maintenance organization representatives, school psychologists) as well as direct and indirect recipients of my service (e.g., school administrators, parents, teachers, students).

That occupational therapy is, as Wood (1996) proposes, close to understanding and articulating its role in promoting adaptation through occupation in a way that the public will comprehend and society will benefit truly represents the promise of our work. I look forward to participating in the production and promotion of ideas, research, and treatment that is driven by such powerful forces.

\section{Reference}

Wood, W. (1996). Legitimizing occupational therapy's knowledge. American Journal of Occupational Therapy, 50, 626-634.

\section{CORRECTION}

To "The Value of Studying Occupation: An Example With Primate Play" by Wendy Wood (May 1996, Volume 50[5], pp. 327-337):

The sentence reading "Chimpanzees and bonobos, both species of apes, possess less than 99\% DNA similarity to humans and thus represent the most closely related nonhuman primate species to ourselves (Zihlman,
1982)" should read "Chimpanzees and bonobos, both species of apes, possess berween $98.7 \%$ and 99\% DNA similarity to humans and thus represent the most closely related nonhuman primate species to ourselves (Zihlman, 1982)."

The AJOT editorial staff regrets this error and hopes that readers were not inconvenienced. 